\title{
Mikroenkapsulasi Likopen dari Buah Tomat dengan Metode Penguapan Pelarut
}

\author{
(Microencapsulation of Lycopene from Tomato Fruit by Solvent Evaporation Method)
}

\author{
Evi Sulastri, Nurlina Ibrahim, Suci Budiarti
}

Jurusan Farmasi, Fakultas Matematika dan Ilmu Pengetahuan Alam,Universitas Tadulako, Palu.

\begin{tabular}{l} 
Article Info: \\
Received: 06 March 2019 \\
in revised form: 20 March 2019 \\
Accepted: 31 March 2019 \\
Available Online: 31 March 2019 \\
\hline \\
Keywords: \\
Tomato \\
Lycopene \\
Microencapsulated \\
Ethyl cellulose \\
Solvent evaporation \\
\hline \\
Corresponding Author: \\
Evi Sulastri \\
Jurusan Farmasi \\
Fakultas MIPA \\
Universitas Tadulako \\
Palu \\
Indonesia \\
Email : evisulas3@ gmail.com
\end{tabular}

Email : evisulas3@gmail.com

\begin{abstract}
Lycopene is a carotenoid group easily damaged due to the oxidation process (light, oxygen and temperature) and isomerization during storage. This damage can be minimized by microencapsulation processes. The objective of this study was to develop novel microencapsulation of lycopene extracts from tomato fruit by solvent evaporation method using ethyl cellulose as wall materials and to select the optimum formulation. Three microcapsule formulations were prepared containing the ratio of lycopene and ethyl cellulose (L:ES) of 1:1, 1:2 and 1:3. The morphology of the microcapsules was analysed by optical microscopy and scanning electronic microscopy. The encapsulation efficiency, particle size, recovery yield and moisture content were also examined. The result showed that all microcapsule formula were aggregated and irregular in shape with encapsulation efficiency of $6.13-19.43 \%$, moisture content of 1,63 $7,52 \%$, recovery yield of $81-98,12 \%$ and particle size of $46,2-86 \mu \mathrm{m}$. Microcapsule with a ratio 1:3 (L:ES) was the most optimum formula based on a maximum encapsulation efficiency than the others.
\end{abstract}

How to cite (APA 6th Style):

Sulastri, E., Ibrahim, N., Budiarti, S. (2019). Mikroenkapsulasi Likopen dari Buah Tomat dengan Metode Penguapan Pelarut. Jurnal Farmasi Galenika :Galenika Journal of Pharmacy, 5(1), 108-116. doi:10.22487/j24428744.2019.v5.i1.12406 


\begin{abstract}
ABSTRAK
Likopen termasuk kelompok karotenoid yang mudah rusak karena proses oksidasi (cahaya, oksigen dan suhu) dan isomerisasi selama penyimpanan. Kerusakan tersebut dapat diminimalkan dengan proses mikroenkapsulasi. Penelitian ini bertujuan untuk mengembangkan sistem mikroenkapsulasi pada formulasi likopen dengan metode penguapan pelarut dan memilih formula yang paling optimum. Proses mikroenkapsulasi dilakukan dengan memvariasikan konsentrasi likopen sebagai bahan aktif terhadap etil selulosa sebagai penyalut (L:ES) dalam 3 formula yaitu F1 (1:1), F2 (1:2) dan F3 (1:3). Mikrokapsul yang diperoleh dikarakterisasi meliputi penentuan nilai efisiensi penjerapan, pemeriksaan bentuk dan morfologi, ukuran partikel, dan pengujian kadar air. Hasil karakterisasi ketiga formula menunjukkan nilai efisiensi penjerapan pada rentang 6.13- $19.43 \%$, kadar air $1.63-7.52 \%$, nilai perolehan kembali yaitu $81-98.12 \%$ serta ketiga formula memiliki bentuk permukaan yang tidak beraturan dan teragregasi dengan ukuran partikel pada rentang 46.2-86 $\mu \mathrm{m}$. Berdasarkan data hasil tersebut dapat disimpulkan bahwa rasio 1:3 (L:ES) merupakan formula yang paling optimum berdasarkan nilai efisiensi penjerapan yang paling besar.
\end{abstract}

Kata kunci: Tomat, likopen, mikrokapsul, etil selulosa, penguapan pelarut.

\section{PENDAHULUAN}

Likopen adalah pigmen alami yang disintesis dari tanaman dan mikroorganisme. Likopen merupakan karotenoid yaitu isomer asiklir dari beta karoten. Likopen adalah hidrokarbon sangat tidak jenuh yang mengandung 11 ikatan rangkap terkonyugasi dan 2 tidak terkonyugasi. Seperti senyawa polyene lainnya, senyawa ini mudah mengalami isomerisasi cis-trans yang diinduksi oleh cahaya, energi panas dan reaksi kimia. Likopen merupakan salah satu antioksidan yang sangat poten dengan kemampuan peredaman singlet oksigen dua kali lebih tinggi dibandingkan beta karoten dan 10 kali lebih tinggi dari alfa tokoferol. Beberapa studi in vitrotelah melaporkan bahwa likopen memiliki aktivitas antioksidan danpotensial dimanfaatkan untuk pengobatan kanker dan kardiovaskular (Agarwal \& Rao, 2000).

Agarwal dan Rao (1998) melaporkan pemberian 60 mg likopen selama tiga bulan pada 30 orang menyebabkan kepadatan plasma kolesterol Low Density Lipoprotein (LDL) mengalami penurunan. Asupan likopen sebesar $40 \mathrm{mg}$ per hari dapat menurunkan oksidasi LDL secara bermakna dan menurunkan kemungkinan terkena penyakit kanker sebesar 50\%. Penelitian lain yang dilakukan oleh Agarwal dan Rao (2000) melaporkan penerapan pola makan yang mengandung likopen seperti jus tomat, sphagetti dengan saos tomat dan ekstrak likopen dari buah tomat kepada 19 orang sehat selama 1 minggu terbukti dapat menurunkan kadar kolesterol LDL.
Beberapa penelitian melaporkan bahwa proses mikroenkapsulasi dapat melindungi zat aktif dari pengaruh lingkungan atau meningkatkan stabilitas sediaan (Aschida dan Adhitiyawarman, 2014; Gamboa, et al, 2011). Sehingga proses mikroenkapsulasi dalam penelitian ini dapat dimanfaatkan untuk tujuan perlindungan likopen terhadap pengaruh lingkungan. Beberapa literatur menunjukkan bahwa likopen yang diproduksi dengan teknik mikroenkapsulasi dapat menjaga stabilitasnya selama penyimpanan (Rocha et al, 2012). Shu et al (2006) melaporkan mikrokapsul likopen menggunakan gelatin dan sukrosa sebagai penyalut dengan teknik spray dryer menghasilkan efisiensi penjerapan 12.1-82.2 \%. Rocha et al (2013) melakukan enkapsulasi likopen dengan teknik complex coaservasi menggunakan gelatin dan gum arab sebagai penyalut menghasilkan efisiensi penjerapan likopen 95.12-99.42\%.

Teknik mikroenkapsulasi telah banyak digunakan untuk melindungi zat aktif dari proses degradasi karena pengaruh cahaya, panas, kelembaban dan udara dengan mengurangi kontak dengan lingkungan. Gamboa et al (2011) melaporkan teknik mikroenkapsulasi terhadap alfa tokoferol menghasilkan efisiensi yang tinggi dan tingkat retensi bahan aktif obat yang tinggi dengan stabilitas yang baik selama penyimpanan. Metode penguapan pelarut merupakan salah satu teknik enkapsulasi yang dapat digunakan untuk bahan inti berupa senyawa yang sukar larut atau kelarutannya kecil dalam air, tidak 
larut dalam pelarut nonpolar, senyawa reaktif (seperti enzim) atau emulsi fotografi. Prinsip dari metode ini adalah proses melarutkan atau mendispersikan zat aktif ke dalam larutan polimer dimana selanjutnya diemulsifikasikan ke dalam fase eksternal berupa air atau minyak. Mikrokapsul akan terbentuk selanjutnya setelah proses difusi/penguapan pelarut dan pengendapan polimer yang digunakan. (Deshmukh et al., 2016).

Pemilihan bahan penyalut/enkapsulasi sangatlah penting untuk efisiensi enkapsulasi dan stabilitas mikrokapsul yang dihasilkan. Etil selulosa merupakan polimer turunan selulosa yang bersifat hidrofobik, sehingga dapat menghalangi lepasnya obat dari sediaan. Etil selulosa larut dalam banyak pelarut organik diantaranya aseton. Aseton bersifat mudah menguap dan digunakan sebagai pelarut untuk formulasi bahan aktif yang sensitif dengan air (Rowe, 2009). Likopen bersifat hidrofobik, sehingga dalam pembentukan mikrokapsuletil selulosa dapat bercampur secara kimia dengan likopen yang menghasilkan mikrokapsul dengan tipe matriks.

Tujuan dari penelitian ini adalah mengembangkan sistem mikroenkapsulasi pada formulasi likopen dengan metode penguapan pelarut dan memilih kondisi perlakuan yang paling optimum.

\section{METODE PENELITIAN}

\section{Alat}

Alat-alat yang digunakan pada penelitian ini antara lain: blender, rotary vakum evaporator $\left(\right.$ Buchi $\left.^{\circledR}\right)$, oven vakum, spektrofotometer UV-Vis $\left(\mathrm{CECIL}^{\circledR} 7410\right)$, neraca analitik $\left(\mathrm{CITIZEN}^{\circledR}\right)$, thermometer, stirer (Denville ${ }^{\circledR}$ Sceintiac Inc), moisture analyzer $\left(\right.$ CITIZEN $^{\circledR}$ MB 200), Freeze dryer, mikroskop cahaya $\left(\mathrm{CARTON}^{\circledR}\right)$, SEM (JEOLJSM-6510LA) dan alat-alat gelas.

\section{Bahan}

Likopen yang digunakan pada penelitian ini diperoleh dari ekstraksi buah tomat yang dikumpulkan dari perkebunan tomat di Kota Palu, Sulawesi Tengah, bahan lainnya yaitu heksan, aseton, etil selulosa, paraffin cair dan tween 80 .

\section{Metodologi}

\section{Produksi Serbuk Likopen Kasar Dari Buah Tomat}

Produksi serbuk likopen kasar dari buah tomat mengikuti metode Mappiratu, et al. (2010): buah tomat dibelah dan ditimbang, selanjutnya ditambahkan air dengan rasio air: daging (1,5:1). Daging buah tomat dihancurkan dengan blender, lalu dipanaskan pada suhu $70^{\circ} \mathrm{C}$ selama 60 menit, selanjutnya disaring. Ampas/residu yang dihasilkan dikeringkan di bawahsinar matahari. Residu kering yang dihasilkan merupakan likopen kasar. Untuk menghasilkan serbuk likopen, residu kasar dihancurkan dengan blender kemudian ditimbang. Rendamen dihitung menggunakan rumus:

Rendemen likopen $\operatorname{kasar}(\%)=$

$$
\frac{\text { Berat serbuk kasar likopen }}{\text { Berat buah tomat }} \times 100 \%
$$

\section{Pemurnian Ekstrak Likopen Kasar}

Pemurnian likopen kasar dilakukan dengan cara ekstraksi likopen hasil pemisahan dari daging buah tomat. Likopen kasar diekstrak dengan pelarut nheksan menggunakan rasio 1:25. Campuran selanjutnya dikocok di atas mesin kocok dengan agitasi $250 \mathrm{rpm}$ selama 1 jam. Ekstraksi dilakukan secara berulang hingga ekstrak yang dihasilkan tidak berwarna. Selanjutnya ekstrak likopen yang dihasilkan dipisahkan dari pelarutnya dengan cara vakum menggunakan rotari vakum evaporator. Ekstrak yang dihasilkan dikentalkan menggunakan gas nitrogen (Mappiratu, et al., 2010). Selanjutnya dihitung rendamennya menggunakan rumus:

Rendemen ekstrak likopen (\%)

$$
=\frac{\text { Berat ekstrak likopen }}{\text { Berat serbuk kasar likopen }} \times 100 \%
$$

\section{Preparasi mikrokapsul likopen dengan metode penguapan pelarut}

Metode mikroenkapsulasi mengikuti Sutriyo et al (2004) dan Murtaza et al (2009) dengan beberapa modifikasi. Mikrokapsul likopen disiapkan dengan 3 perbandingan inti (likopen) terhadap penyalut (etil selulosa) yaitu F1(1:1), 
F2(1:2), dan F3(1:3). Etil selulosa dilarutkan dengan pelarut aseton $(15 \mathrm{ml})$ di dalam gelas kimia, selanjutnya likopen didispersikan ke dalam larutan etil selulosa (A). Di dalam gelas kimia lain campurparafin cair $(30 \mathrm{ml})$ dan tween 80 (1ml) (B). Selanjutnya campuran A ditambahkan tetes demi tetes dan diemulsikan dalam campuran B hingga terbentuk emulsi. Emulsi diaduk menggunakan stirer dengan beberapa kecepatan pengadukan yaitu 750 rpm, $1000 \mathrm{rpm}$, dan $1200 \mathrm{rpm}$ selama 30 menit, pada temperatur ruang sampai semua aseton menguap. Mikrokapsul dipisahkan dengan cara disentrifugasi hingga filtrat dan residunya terpisah. Kemudian residu yang didapatkan dikeringkan dengan freeze dryer.

\section{Karakterisasi Mikrokapsul}

\section{Pemeriksaan Morfologi Mikrokapsul}

Morfologi mikrokapsul yang terbentuk diamati menggunakan alat SEM (Scanning Electron Microscope) dan mikroskop cahaya.Pemeriksaan menggunakan SEM dilakukan dengan cara sampel mikrokapsul diletakkan pada sample holderdengan ketebalan $10 \mathrm{~nm}$ kemudian disalut dengan partikel emas menggunakan fine coater. Sampel kemudian diperiksa dan dilihat morfologinya pada intensitas 20 $\mathrm{kV}$ dengan perbesaran 50 dan 200 kali (Murtaza et al., 2009).

\section{Pengukuran Partikel Mikrokapsul}

Pengukuran partikel mikrokapsul menggunakan mikroskop yang dilengkapi dengan mikrometer. Mikroskop sebelum digunakan dikalibrasi terlebih dahulu menggunakan mikrometer pentas. Sejumlah mikrokapsul didispersikan dalam parafin cair lalu diteteskan pada kaca objek. Selanjutnya diletakkan di bawah mikroskop dan diamati ukuran partikel serbuk (Aulton, 2002).

\section{Uji Perolehan Kembali (UPK)}

UPK dihitung berdasarkan perbandingan bobot mikrokapsul yang didapat terhadap total massa bahan aktif dan penyalut yang digunakan (Waghulde \& Naik, 2017).

\section{Penetapan Kadar Air}

Kadar air ditentukanmenggunakan alat moisture balance. Terlebih dahulu alat dipanaskan selama 10 menit, kemudian \pm 1 gram mikrokapsul diletakkan dalam wadah alumunium secara merata. Suhu diatur pada angka $105^{\circ} \mathrm{C}$, kemudian pengukuran dilakukan. Nilai yang terbaca pada moisture balance dicatat sebagai kadar air mikrokapsul.

\section{Penentuan Nilai Efisiensi Penjerapan}

Mikrokapsul ditimbang $200 \mathrm{mg}$, digerus dalam lumpang, kemudian dilarutkan dalam $25 \mathrm{ml}$ n-heksan hingga mikrokapsul terlarut sempurna. Dipipet $5 \mathrm{ml}$ ke dalam labu ukur $10 \mathrm{ml}$ dan ditambahkan pelarut nheksan hingga tanda batas. Serapan likopen diukur pada panjang gelombang $470 \mathrm{~nm}$ dengan spektrofotometer UV-Vis (Shu et al., 2006). Efisiensi penjerapan dihitung dengan persamaan berikut:

$$
\begin{aligned}
& \text { Efisiensi penjerapan (\%) } \\
& =\frac{\text { jumlah likopen yang terenkapsulasi }}{\text { jumlah likopen teoritis }} \times 100
\end{aligned}
$$

\section{Analisis Data}

Pengamatan morfologi mikrokapsul dan pengamatan ukuran partikel dianalisis secara deskriptif sedangkan data hasil uji perolehan kembali, kadar air dan efisiensi penjerapan dianalisis secara statistik menggunakan metode ANOVA (Analisis of Variance).

\section{HASIL DAN PEMBAHASAN}

\section{Pengaruh Kecepatan Pengadukan}

Proses mikroenkapsulasi menggunakan teknik penguapan pelarut pada penelitian ini dilakukan dengan pembawa cair yaitu pembentukan emulsi minyak dalam air dengan pengadukan dari dua cairan yang tidak saling bercampur. Proses ini melibatkan pelarutan polimer yang digunakan sebagai penyalut dalam pelarut yang mudah menguap dan tidak bercampur dengan cairan pembawa yang digunakan. Proses pembentukan mikrokapsul dimulai ketika memisahnya emulsi tetesan fase terdispersi dalam fase pembawa membentuk tetesan kecil. Hal ini disebabkan karena mulai pecahnya emulsi akibat penguapan aseton dan ketika pengadukan dihentikan 
maka mikrokapsul yang terbentuk akan turun ke dasar wadah. Penambahan tween 80 sebagai emulgator akan meminimalkan terjadinya penggumpalan partikel menjadi agregat dan mengurangi tegangan antar muka antara fase minyak dan air sehingga terbentuk emulsi yang cukup stabil selama emulsifikasi pembentukan mikrokapsul.

Tabel 1. Hasil orientasi kecepatan pengadukan mikroenkapsulasi likopen

\begin{tabular}{cccc}
\hline & \multicolumn{3}{c}{ Kecepatan Pengadukan } \\
\cline { 2 - 4 } Parameter & $\begin{array}{c}\mathbf{7 5 0} \\
\text { rpm }\end{array}$ & $\begin{array}{c}\mathbf{1 0 0 0} \\
\text { rpm }\end{array}$ & $\begin{array}{c}\mathbf{1 2 0 0} \\
\text { rpm }\end{array}$ \\
\hline $\begin{array}{c}\text { Nilai perolehan } \\
\text { kembali }(\%)\end{array}$ & 81 & 77 & 74.5 \\
$\begin{array}{c}\text { Ukuran partikel } \\
(\boldsymbol{\mu m})\end{array}$ & $30-230$ & $5-100$ & $5-95$ \\
$\begin{array}{c}\text { Efisiensi } \\
\text { enkapsulasi }(\%)\end{array}$ & 5.17 & 1.58 & 1.19 \\
\hline
\end{tabular}

Kecepatan 750 rpm dipilih sebagai kecepatan optimum dalam membentuk mikrokapsul berdasarkan pada hasil rentang ukuran mikrokapsul yang diperoleh yaitu30-230 $\mu$ mdan efisiensi penjerapan mikrokapsul yang diperoleh $5.17 \%$ dengan nilai perolehan kembali $81 \%$ (tabel 1). Ukuran partikel dapat dipengaruhi oleh kecepatan pengadukan, semakin besar kecepatan pengadukan maka semakin kecil ukuran partikel yang dihasilkan. Tetapi pada metode pengadukan stirer yang digunakan pada penelitian ini kurang efektif dalam pembentukan mikrokapsul, dimana bahan aktif banyak yang terbuang pada saat pengadukan akibat kekuatan pengadukan yang terlalu besar sehingga semakin cepat pengadukan maka efisiensi penjerapan semakin kecil. Oleh karena itu, dipilih kecepatan pengadukan $750 \mathrm{rpm}$ karena menghasilkan efisiensi penjerapan yang lebih besar. Selanjutnya hasil orientasi yang terpilih tersebut kemudian digunakan pada proses pembuatan mikrokapsul likopen dalam 3 formula dengan perbandingan zat aktif terhadap bahan penyalut yang berbeda setiap formula.

\section{Karakterisasi Mikrokapsul Likopen}

Ketiga formula mikrokapsul yang dihasilkan dengan metode penguapan pelarut menghasilkan serbuk mikrokapsul likopen berwarna orange (gambar 1).

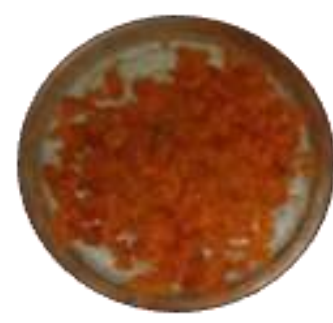

A

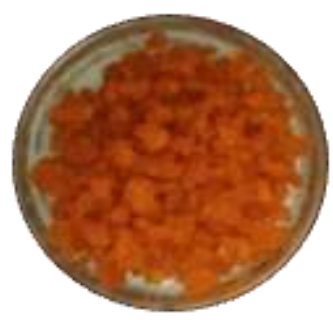

B

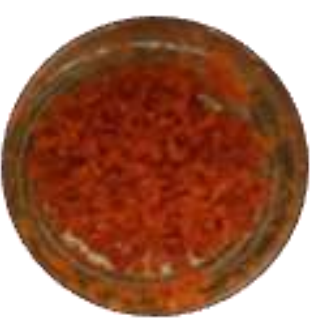

C

Gambar 1. Sediaan Miroenkapsul Likopen. A. mikrokapsul F1, B. mikrokapsul F2, C. mikrokapsul F3.

Hasil pengamatan bentuk dan morfologi mikrokapsullikopen yang dilakukan dengan foto SEM (gambar 2) pada perbesaran 50 kali dan perbesaran 200 kali terlihat seluruh permukaan mikrokapsul yang tidak beraturan dengan tipe matriks. Sedangkan hasil pengamatan menggunakan mikroskop cahaya (gambar 3) pada perbesaran 100 kali terlihat bentuk ukuran mikrokapsul yang bervariasi dan pada perbesaran 400 kali bentuk mikrokapsul yang tidak sferis (bulat). Hal ini kemungkinan disebabkan padaproses pengadukan menggunakan stirer dengan kecepatan yang tinggi memecah partikel mikrokapsul menjadi partikel dengan ukuran yang lebih kecil dengan bentuk yang tidak sferis. 

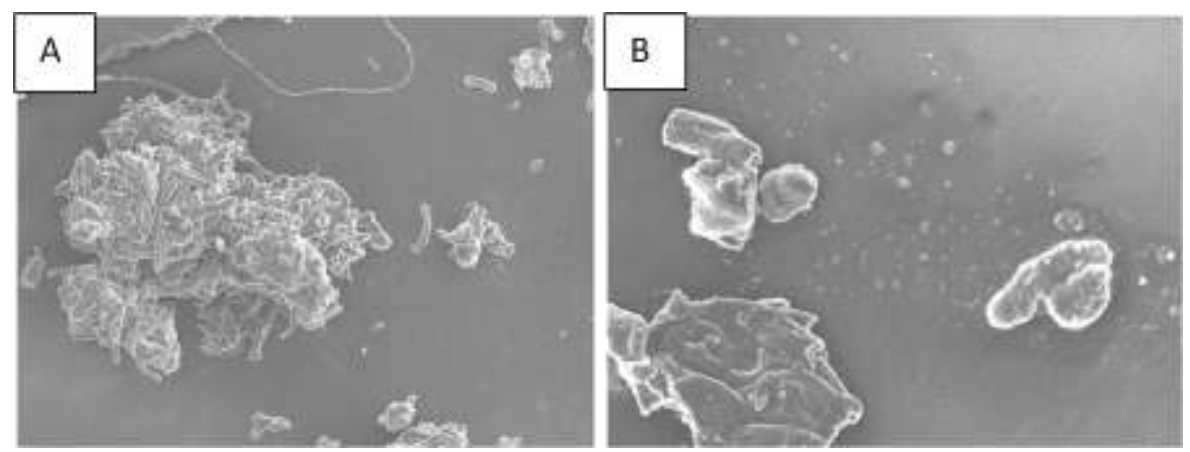

Gambar 2. Bentuk morfologi mikrokapsullikopen F3 (sebagai representatif formula) menggunakan SEM (A) perbesaran 50 X (B) perbesaran $200 \mathrm{X}$

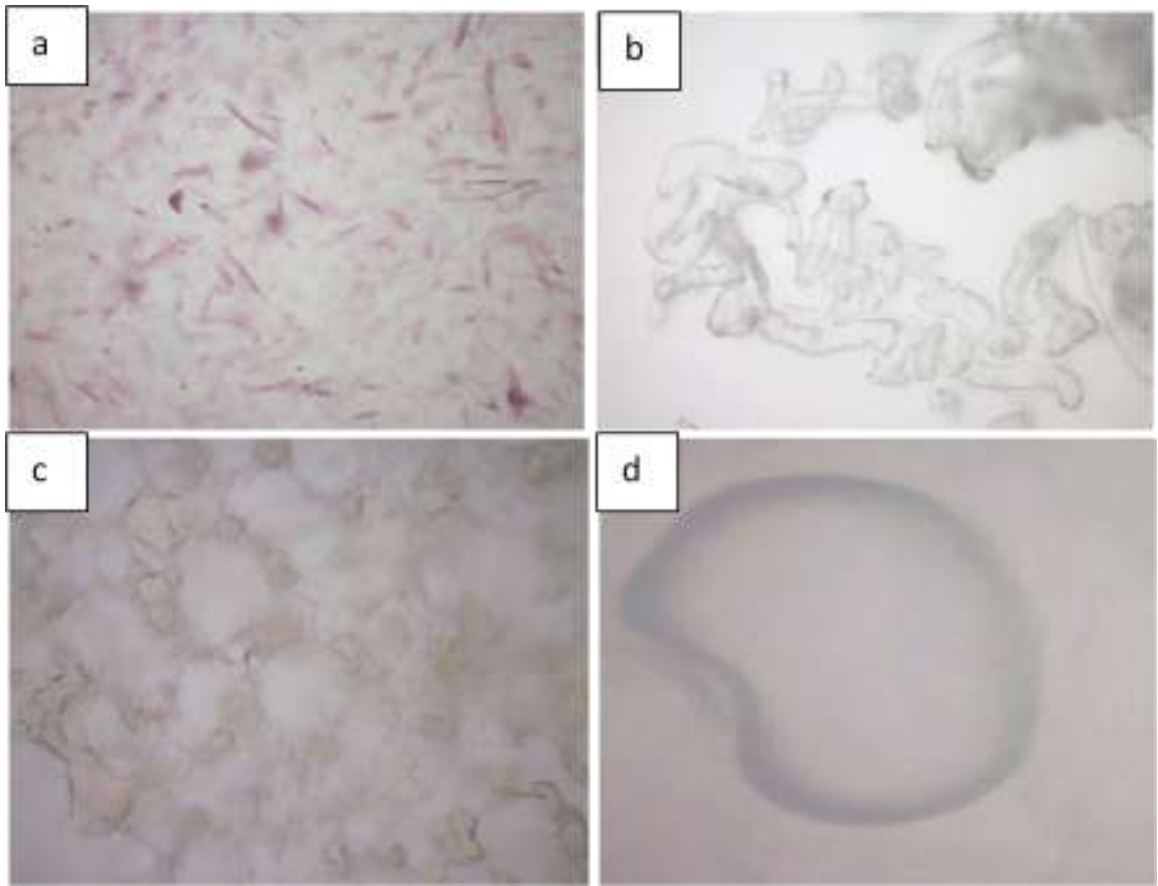

Gambar 3. Bentuk morfologi mikrokapsullikopen menggunakan mikroskop cahaya (a) likopen perbesaran $100 \mathrm{X}$ (b) etil selulosa perbesaran $100 \mathrm{X}$ (c) mikrokapsul F3 perbesaran $100 \mathrm{X}$ (d) mikrokapsul F3 perbesaran $400 \mathrm{X}$

Terdapat perbedaan yang signifikan antara ketiga formulapada nilai perolehan kembali dengan range nilai $81-98.12 \%$. Nilai tersebut menunjukkan bahwa perolehan kembalinya kurang dari $100 \%$ (tabel 2). Hal ini kemungkinan disebabkan oleh belum sempurnanya proses emulsifikasi yang terjadi sehingga ada zat yang tidak tersalut dan ikut terbuang bersama parafin cair. Selain itu, disebabkan oleh kurang efektifnya metode stirer yang digunakan (seperti telah disebutkan sebelumnya) pada saat proses pengadukan.
Tabel 2. Hasil Karakterisasi Mikrokapsul Likopen

\begin{tabular}{cccc}
\hline Karakteristik & F1 (1:1) & F2 (1:2) & F3 (1:3) \\
\hline $\begin{array}{c}\text { Nilai Perolehan } \\
\text { Kembali (\%) }\end{array}$ & $81 \pm 0,71$ & $87.83 \pm 0,23$ & $98.12 \pm 0.53$ \\
$\begin{array}{c}\text { Kadar air (\%) } \\
\text { Ukuran } \\
\text { partikel ( } \boldsymbol{\mu m}) \\
\begin{array}{c}\text { Efisiensi } \\
\text { Penjerapan } \\
(\%)\end{array}\end{array}$ & $1.63 \pm 0.06$ & $2.63 \pm 0.05$ & $7.52 \pm 0.04$ \\
\hline
\end{tabular}


Perbedaan ukuran partikel mikrokapsul pada F1, F2 dan F3 dapat dilihat pada gambar 4. Hasil uji ukuran partikel secara umum memperlihatkan bahwa ukuran mikrokapsul terletak antara 30-210 $\mu \mathrm{m}$. Rentang ukuran partikel terbanyak pada formula 1 dan formula 2 berada pada rentang yang sama yakni pada rentang 30-60 $\mu \mathrm{m}$ dengan frekuensi formula 1 dan formula 2 secara berturut-turut sebesar $40 \%$ dan $32 \%$ sedangkan formula 3 memiliki ukuran partikel terbesar pada rentang ukuran $61-90 \mu \mathrm{m}$ sebesar $25 \%$. Ukuran partikel selain dipengaruhi oleh kecepatan pengadukan (seperti yang telah dijelaskan di atas), dapat pula dipengaruhi oleh jumlah etil selulosa yang digunakan sebagai pembentuk dinding mikrokapsul, semakin tinggi konsentrasi penyalut yang digunakan maka semakin besar ukuran partikelnya(Sutriyo et $a l$. , 2004). Hal ini juga sejalan dengan penelitian yang dilakukan oleh Rahman et al (2010) yang melaporkan dengan meningkatnya jumlah polimer yang digunakan menyebabkan peningkatan ukuran partikel mikrokapsul yang dihasilkan. Di samping itu, peningkatan viskositas dari sistem dispersi obat yang dapat disebabkan karena meningkatnya konsentrasi polimer yang digunakan menghasilkan partikel dengan ukuran yang besar karena kekuatan pengadukan yang tinggi diperlukan untuk memecahkan tetesan partikel (Freitas et al., 2005).

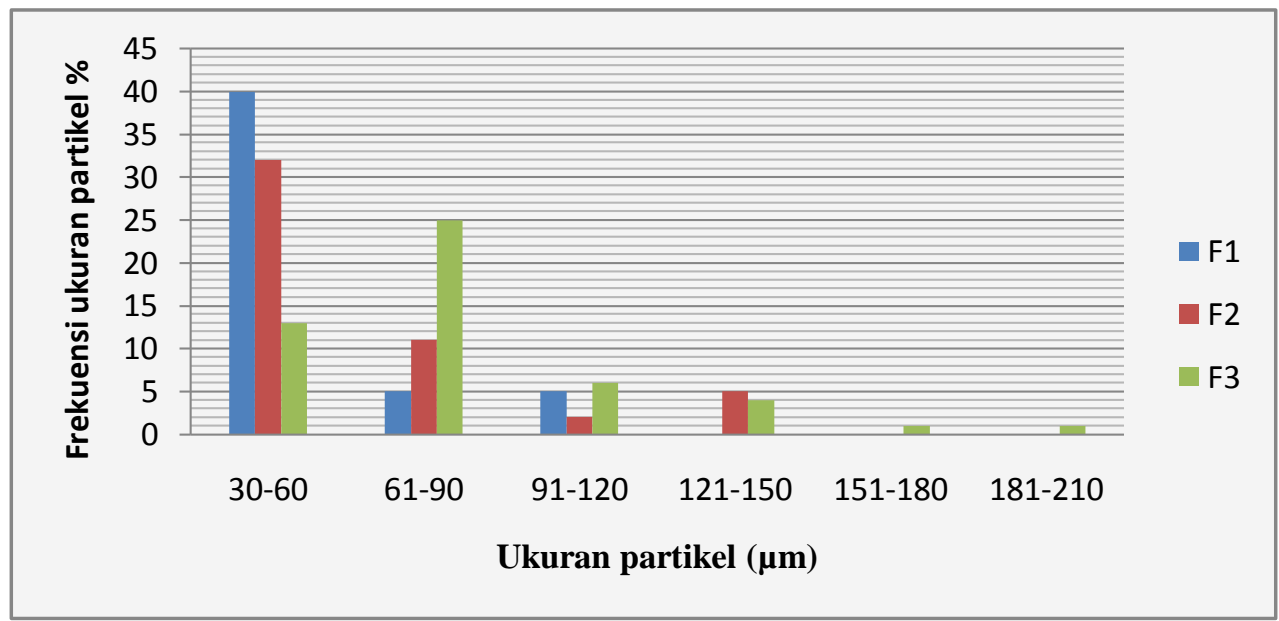

Gambar 4. Grafik Pengaruh Ukuran Partikel Mikrokapsul Likopen terhadap Frekuensi Ukuran Partikel

Nilai kadar air ketiga formula berada pada rentang 1.63 sampai $7.52 \%$. Pada tabel 2 terlihat bahwa semakin besar penyalut etil selulosa yang digunakan maka semakin besar pula kadar air dalam mikrokapsul. Hal ini kemungkinan disebabkan oleh kadar air dalam etil selulosa yang besar. Dari hasil uji pendahuluan diperoleh kadar air etil selulosa sebesar $8,91 \%$. Semakin tinggi kandungan air pada suatu sediaan dapat mengakibatkan mudahnya sediaan tersebut terkontaminasi oleh mikroba sehingga nilai kadar air perlu dikontrol. Selain itu, apabila mikrokapsul ini selanjutnya diinginkan untuk dikembangkan ke dalam bentuk sediaan tablet maka kandungan air perlu diperhatikan karenadapat berpengaruh terhadap laju alir dan indeks kompresibilitas serbuk sehingga bila kadar airnya besar menyebabkan serbuk sulit dicetak menjadi tablet.
Efisiensi penjerapan ketiga formula berada pada rentang 6.13-19.43\% dan secara statistik berbeda signifikan untuk ketiga formula. Shu et al (2005) melaporkan bahwa ketika kemurnian likopen yang dienkapsulasi kurang dari 52\% menghasilkan efisiensi enkapsulasi yang sangat kecil sekitar 12-32 $\%$, tetapi signifikan meningkat sekitar $82 \%$ ketika kemurnian likopen $52 \%$ atau lebih. Roscha et al. (2012) menghasilkan mikrokapsul likopen dengan nilai efisiensi penjerapan sekitar $21.01 \%$ sampai $29.73 \%$ menggunakan metode spray dryer. Rendahnya nilai efisiensi penjerapan dapat pula dihubungkan dengan mudahnya likopen terurai baik karena oksidasi maupun isomerisasi karena pengaruh lingkungan. Selama proses dan penyimpanan, likopen dapat mengalami oksidasi dan isomerisasi yang mengakibatkan perubahan dari bentuk trans menjadi mono-cis atau poly-cis yang disebabkan oleh pengaruh panas, cahaya ataupun reaksi kimia (Xianquan et al., 2008). 
Berdasarkan nilai efisiensi penjerapan ketiga formula, menunjukkan bahwa semakin tinggi konsentrasi etil selulosa maka semakin besar likopen yang terjerap. Etil selulosa sebagai bahan penyalut yang membentuk dinding kapsul mampu melindungi likopen dengan baik sehingga akan meningkatkan nilai efisiensi penjerapan mikrokapsul likopen. Kelebihan etil selulosa sebagai bahan penyalut diantaranya dapat menghasilkan salut tipis yang lebih kuat dan lebih keras sehingga dapat meningkatkan sifatnya sebagai penghalang. Sedangkan pada formula yang bahan penyalutnya sedikit, maka zat aktif yang terjerap sedikit pula karena bahan penyalut kurang optimal dalam melindungi zat aktif tersebut.

\section{KESIMPULAN}

Pengembangan formulasi likopen dengan teknik mikroenkapsulasi penguapan pelarut menggunakan etil selulosa sebagai penyalutmenghasilkan mikrokapsul dengan karakteristik spesifik dimana dengan variasi konsentrasi etil selulosa memberikan perbedaan signifikan terhadap karakteristik mikrokapsul yang diperoleh. Semakin tinggi konsentrasi etil selulosa yang digunakan, maka semakin besar nilai UPK, ukuran partikel, kadar air dan efisiensi penjerapannya. Bagaimanapun, ukuran partikel dan kadar air yang dihasilkan masih dalam rentang yang diinginkan. Sehingga, dari tiga formula yang dikembangkan berdasarkan perbedaan rasio zat aktif terhadap penyalutdirekomendasikan F3 sebagai formula yang paling optimum dengan nilai efisiensi penjerapan yang paling besar.

\section{DAFTAR PUSTAKA}

Agarwal, S., \& Rao, A.V. (1998). Tomato Lycopene and Low Density Lipoprotein Oxidation: A Human dietary intervention study, Lipids, 33: $981-984$.

Agarwal S., \& Rao A.V. (2000). Role of Antioxidant Lycopene in Cancer and Heart Diseases, Journal of the American College of Nutrition, 19(5).

Aulton, M.E. (2002). Pharmaceutics: The Science of Dosage Form Design, Second Edition, Churchill Livingstone

Benita, S. (1991). Microencapsulation Methods and Industrial Application, New York, Marcel Dekker Inc.
Benita, S. (2006). Microencapsulation: methods and industrial application, (Edisi 2), Boca Raton: CRC Press.

Deshmukh, R., Wagh, P., Naik, J. (2016). Solvent evaporation and spray drying technique for micro-and nanospheres/particles preparation: A Review, Drying Technology, 34(15), 1758 1772

Di Mascio, P.D., S. Kaiser dan H. Seis. (1989). Lycopene as the most efficient biological carotenoid singlet oxygen quencher, Arch. Biochem, Biophys, 274: 532 - 538.

Febriyenti, Ben, E.S., Prima, T. (2013). Formulasi Mikrokapsul Glikuidon Menggunakan PenyalutEtil Selulosa dengan Metode Emulsifikasi Penguapan Pelarut, Prosiding Seminar Nasional Perkembangan Terkini Sains Farmasi dan Klinik, Oktober 2013, Padang

Freitas, S., Merkle, H.P., Gander, B. (2005) Microencapsulation by solvent extraction/evaporation: reviewing the state of the art of microsphere preparation process technology, Journal of Controlled Release 102 (2) $313-332$

Gamboa, O.D., Goncalves, L.G., Grosso, C.F. (2011). Microencapsulation of tocopherols in lipid matrix by spray chilling method, Procedia Food Science, 1, 1732-1739

Mappiratu, Nurhaeni dan I. Israwaty. (2010). Pemanfaatan Tomat Afkiran untuk Produksi Likopen, Media Litbang SulTeng, 3 (1): 64-69.

Murtaza, G., Ahamd, M., Akhtar, N., Rasool, F. (2009). A Comparative Study of Various Microencapsulation Techniques: Effect of Polymer Viscosity on Microcapsule Characteristics, Pak. J. Pharm. Sci., 22 (3), 291-300.

Rahman, M.M., Islam, M.S., Sharmin, N., Chowdhury, J.A., Jalil,R. (2010). Preparation and Evaluation of Cellulosa Acetate Phthalate and Ethyl cellulose Based Microcapsules of Diclofenac Sodium using Emulsification and Solven-Evaporation Method, Dhaka Univ. J. Pharm. Sci. 9(1): 39-46 
Rocha, G.A., Favaro-Trindade, C.S., Grosso, C.R.F. (2012). Microencapsulation of Lycopene by Spray Drying: Characterization, Stability and Application of Microcapsules, Food and Bioproducts Processing, 90, 37-42.

Rocha-Selmi, G.A., Favaro-Trindade, C.S., Grosso, C.R.F. (2013). Morphology, Stability, and Application of Lycopene Microcapsules Produced by Complex Coacervation, Journal of Chemistry, 2013

Rowe, Raymond C., Paul J Seshkey, \& Marian E Quinn. (2009). Handbook of Pharmaceutical Exipients Sixth Edition, Pharmaceutical Press, London.

Shu, B., Yu, W., Zhao, Y., Liu, X. (2006). Study on Microencapsulation of lycopene by Spraydrying, Journal of Food Engineering, 76, 664669

Sutriyo, Djajadisastra, J., \& Novitasari, A. (2004). Mikroenkapsulasi Propanolol Hidroklorida dengan Penyalut Etil Selulosa Menggunakan Metoda Penguapan Pelarut, Majalah Ilmu Kefarmasian, I, 93 - 101.

Waghulde, M., \& Naik, J. (2017). Comparative study of encapsulated vildagliptin microparticles produced by spray drying and solvent evaporation technique, Drying Technology, $35: 13,1644-1654$.

Xianquan, S., Shi, J., Kakuda, Y., Yueming, J. (2005). Stability of Lycopene during food processing and storage, J Med Food., 8(4), 413-422. 